magnates of the Grand Duchy. It is a highly patriotic work with a marked anti-Polish bias, probably caused by anxiety for the future of the Grand Duchy of Lithuania which was in danger of losing its political independence and identity in the imminent union with Poland.

The great difficulty in the study of the Byelorussian chronicles of the $15-16$ th century is the fact that their authors, as well as the exact place and time of their original, are unknown. The student is thus often compelled to indulge in suppositions which are more or less probable. The same applies to the conclusions of Camiarycki, although it must be added that his arguments, based on a thorough analysis of the texts, are very convincing. His proposed new classification of the chronicle is most certainly a step in the right direction and malkes more sense than the previcus system which created more difficulties than it solved. In several important points Camiarycki differs from other scholars, such as Florja, Ochmański and even such an authority as Sachmatov.

In a book of such modest size it is impossible to treat all aspects of the problem with equal thoroughness, and the author is forced to establish his priorities. Thus Camiarycki devotes the great part of his work (about 120 pages) to the study of the first chronicle which, according to him, is 'the most complex in its composition... and forms the basis for all subsequent Byelorussian-Lithuanian chronicle writing' (p. 188).

On the whole Camiarycki has succeeded in producing an interesting and valuable work which sheds new light on the origin and composition of Byelorussian chronicles of the 1516 th centuries. It is a good beginning and it is hoped that he will continue to show interest in this subject and be followed in due time by other Byelorussian scholars. But firstly one would like to echo the following wish of the author: "The time has come to prepare and publish a more complete, improved collection of ByelorussianLithuanian and Byelorussian chronicles of the 15-18th centuries, because the 1907 edition ... is both incomplete and in many ways antiquated. Moreover it has long become a bibliographical rarity even for specialists' (p. 190).

\section{A. Nadson}

\title{
Ostrowski, W. The Ancient Names and Early Cartography of Byelorussia. A revised edition with 50 reproductions. Published by the author, London, 1971. 19 pages.
}

The author concludes his text by stating that his object was to supply a brief introduction to the history of the cartography of Byelorussia. In fact his book succeeds in doing much more than this. The maps here reproduced span almost four centuries, and are in themselves of inestimable value to historians. In the introduction Ostrowski goes into great detail on the mass of confusing terminology which has been used over the ages to refer to the area of Lithuania, Byelorussia and the Ukraine. From a linguistic point of view, it is doubtful whether anything useful can now be achieved in English to arrive at a more precise terminology; certainly there is nothing to be gained by the invention of new adjectives such as Ruśian', in an attempt to echo the difference in Polish between 'ruski' and rosyjski', since such new coinages have to be explained. It would seem just as easy to maintain the traditional words, but using more precise definitions of them - a task which many historians have avoided. Byelorussians and Ukrainians will probably have to reconcile themselves to the fact that many writers will continue to use 'Russian' to mean 'East Slavonic' and 'Great Russian', depending on context. Equally, the word 'Rus", originally applied solely to the Kievan 'State', is now found with reference to the Muscovite state of the sixteenth and seventeenth centuries, particularly in modern Russian works. Whether politically motivated or not, a semantic shift has taken place, and the word has acquired antiquarian rather than geographical significance. Ostrowski's achievement is to have listed the various names found in the maps, and given them a careful analysis. The 
maps are both political and ethnographic, the latter including oddities like Rusak's map of 1939 which has ethnic Byelorussia extending as far north as the Gulf of Finland! All the reproductions are very clear and, where possible, the British Museum pressmark of each book and map is given, thus making the work a useful reference guide.

Anuškin, A. Na zare knigopečatanija v Litve. 'Mintis', Vilna, 1970. 196 pages.

The book aims to give a survey from a Marxist point of view - of book production in Lithuania in the sixteenth and early seventeenth centuries. Litva cannot in this context be interpreted as either the whole of the Grand Duchy of Lithuania or as the ethnic Lithuanian area of Samogitia, but as the territory of the present-day Lithuanian S.S.R., since most of the books discussed were printed in Vilna. Since Anuškin apparently regards Vilna in the sixteenth century as the capital city of ethnic Lithuania, rather than as the capital of a multi-national state, he is forced into using muddled terminology to describe languages and nations. Books were written in Byelorussian, Russian (Byelorussian), Russian (Ukrainian) or simply Russian. Rymša wrote his verses in Russian (Byelorussian) (p. 16) and in Byelorussian (p. 67). The Statute of 1588, itself written in Byelorussian (p. 61), declared Russian (Byelorussian) as the official language of the Grand Duchy (p. 62). The title of the work Rozmowa Polaka $z$ Litwinem is misleadingly translated into Russian as Rozmova poljaka s litovcem - misleading, because 'Litwin' was used at the time to denote a citizen of the Grand Duchy rather than an ethnic Lithuanian. The adjectives belorusskij and ukrainskij are fairly used to describe nations (usually in conjunction with the adjective 'bratskij'), but the hoary zapadnorusskij is brought out of dishonourable retirement, although admittedly to refer to no more than a writing style. Rus' is used to refer to the Muscovite state, and the words 'naša strana' clearly mean the Soviet Union.

There is evidence of similar confusion when dealing with foreign nationalities. Erasmus, although named as 'Erazm Rotterdamskij', is everywhere called a German humanist. The point at issue here is not so much that the nationality is incorrect, as that any mention of nationality is irrelevant in the context of the Renaissance. Both Erasmus and Skaryna were truly international figures of their time, standing head and shoulders above the puny cliché descriptions given them in this book. Moreover, to describe the co-operation in the Vilna printing shops between Lithuanians, Byelorussians and Russians as evidence of friendship between 'fraternal peoples' is to fail to understand what the Renaissance was really about. Anuškin calls it 'curious' that certain theological writers should have quoted more from classical authors than from the Church Fathers. In the context of the excitement of the rediscovery of classical Greek philosophy there is nothing curious at all in this. Another important aspect of Renaissance intellectual life which the author (or his Marxist point of view) does not come to grips with is the thin dividing line between empirical and speculative science. The final section on astrology of Dyblinski's Centuria Astronomica is dismissed as the least interesting part of the book, added, in Anuškin's words, 'to protect the author from the Church censors who might otherwise have taken offence at the more scientific (and therefore anti-official) sections on astronomy proper'. Many scientists of the period would not have made the distinction between astronomy and astrology - Kepler was one of them - just as Newton was quite capable of dabbling in alchemy. In any case this curt dismissal of an intrinsic part of scholarly study could be turned against Anuškin himself. Why has he inserted the apparently irrelevant quotations from Engels on Thomas Münzer? Either he believes that they do serve a purpose, or else he is seeking to appease the censors. Why is the reader told that some works of Andrei Wolan, Stefan Ziza- 